\title{
Control of asthma in Canada: Failure to achieve guideline targets
}

\author{
Kenneth R Chapman MD MSc FRCPC ${ }^{1}$, Pierre Ernst MD MSc FRCPC ${ }^{2}$, A Grenville ${ }^{3}$, \\ $\mathrm{P}$ Dewland $\mathrm{BA}^{4}$, Sabrina Zimmerman $\mathrm{BSc}^{4}$ \\ ${ }^{1}$ Division of Respiratory Medicine, University of Toronto, Toronto, Ontario; \\ ${ }^{2}$ Division of Respiratory Medicine, McGill University, Montreal, Quebec; ${ }^{3}$ Angus Reid Group, \\ Toronto, Ontario and Montreal, Quebec; ${ }^{4}$ GlaxoSmithKline, Mississauga, Ontario
}

KR Chapman, P Ernst, A Grenville, P Dewland, $S$ Zimmerman. Control of asthma in Canada: Failure to achieve guideline targets. Can Respir J 2001;8(Suppl A): 35A-40A.

OBJECTIVE: To assess the degree of asthma control achieved by patients with asthma in Canada and to describe the impact of poor asthma control.

DESIGN: Population-based, cross-sectional telephone interview survey of Canadians with doctor-diagnosed asthma. SUBJECTS AND METHODS: Random digit dialing was used to identify a representative sample of Canadians with asthma. A total of 801 adults and 200 parents of children aged four to 15 years were interviewed over the telephone. Telephone interviews were also conducted with 266 physicians.

RESULTS: Only 24\% of patients achieved disease control by meeting the six symptom-based criteria listed by the 1996 Canadian Asthma Consensus Guidelines as appropriate treatment targets. Fifty-seven per cent of patients failed to meet two or more of the six control criteria and were considered poorly controlled. Fifty-one per cent had required urgent care for out of control asthma at least once in the year before the survey. Nonetheless, $91 \%$ of patients thought that their asthma was adequately controlled. Physicians shared this optimism: $77 \%$ of family physicians and $90 \%$ of respirologists believed that they were usually able to achieve optimal asthma control in their patients. Few physicians gauged asthma control by tracking more than one or two symptoms, and just over one-half (54\%) of patients surveyed recalled ever having had a lung function test. One-half $(48 \%)$ of patients with poorly controlled asthma who used inhaled steroids did not understand the role of inhaled steroids; onethird (32\%) of patients with poorly controlled asthma who used short acting bronchodilators misunderstood the action of quick relief bronchodilators.

CONCLUSIONS: The majority of Canadians with asthma suffer from inadequate control of their disease. Suboptimal control of asthma is associated with excess health care use. Inadequate monitoring by physicians and poor patient education may be factors contributing to this problem.

Key Words: Health care use; Spirometry; Survey; Symptoms

\section{La maîtrise de l'asthme au Canada :} Les objectifs ne sont pas atteints

OBJECTIF : Évaluer le degré de maîtrise de l'asthme obtenu par les patients asthmatiques au Canada et décrire l'impact d'une piètre maîtrise de l'asthme.

MODÈLE : Sondage téléphonique transversal basé dans la population auprès des Canadiens dont l'asthme a été diagnostiqué par un médecin.

SUJETS ET MÉTHODES : Un système de composition aléatoire a été utilisé pour dresser un échantillon représentatif de Canadiens asthmatiques. En tout, 801 adultes et 200 parents d'enfants âgés de quatre à quinze ans ont été interrogés par téléphone. Des entrevues téléphoniques ont également été effectuées auprès de 266 médecins. RÉSULTATS : Vingt-quatre pour cent seulement des patients sont parvenus à maitriser leur maladie selon les six critères symptomatiques énumérés dans les directives canadiennes consensuelles sur

voir page suivante 
l'asthme de 1996 comme objectif thérapeutique. Cinquante-sept pour cent des patients ne répondaient pas à deux ou plus des six critères de maîtrise et leur état a été jugé mal maîtrisé. Cinquanteet-un pour cent avaient eu besoin de soins d'urgence pour un asthme non maîtrisé au moins une fois au cours de l'année précédant le sondage. Néanmoins, $91 \%$ ont estimé que leur asthme était bien maîtrisé. Les médecins étaient du même avis, 77 \% des médecins de famille et $90 \%$ des pneumologues ont dit être, en général, capables d'obtenir une maîtrise optimum de l'asthme chez leurs patients. Peu de médecins ont évalué la maîtrise de l'asthme en se fiant à plus d'un ou deux symptômes et à peine plus de la moitié (54\%) des patients interrogés se sont rappelés avoir subi un test de fonction pul-
INC, DOPNONT COPY

atients dont l'asthme était mal maîtrisé et qui ont utilisé des corticostéroïdes par inhalation ne comprenaient pas le rôle de ces médicaments. Le tiers (32\%) des patients dont l'asthme était mal maîtrisé et qui ont utilisé des bronchodilatateurs à action brève en comprenaient mal le mode d'action.

CONCLUSION : La majorité des Canadiens asthmatiques mâ̂trisent mal leur maladie. Une maîtrise sous-optimale de l'asthme est associée à un recours supplémentaire aux soins de santé. Une surveillance inadéquate exercée par les médecins et un enseignement insuffisant aux patients peuvent être des facteurs qui contribuent à ce problème.
$\mathrm{I}^{\mathrm{n}}$ $\mathrm{n}$ the past decade, we have witnessed a dramatic shift in approaches to asthma management not only in Canada, but also among other developed nations. Once regarded as a disease of airflow obstruction best treated with bronchodilators (1), asthma is now seen as an inflammatory disease of the airways best managed in a preventive fashion with an emphasis on regular, anti-inflammatory medication when symptoms persist (2). In Canada and elsewhere, this strategy has been encouraged by the development of consensus guidelines $(3,4)$. Key to these guidelines are agreed-upon goals of therapy. Stated simply, patients should enjoy freedom from asthma disability, have normal lung function, and suffer few, if any, day to day symptoms of cough, wheeze or breathlessness. It is often said that Canada's first such guidelines for asthma management were published in 1990, although a more official multidisciplinary process for guideline development was not adopted until 1995 (2,5). The Canadian Asthma Consensus (CAC) Guidelines continue to be revised, and with the latest revision, plans were made to disseminate their contents and to encourage their implementation (6). Unfortunately, this process of guideline development, revision and dissemination has taken place in relative ignorance of the actual status of asthma control in Canada, at least as expressed in terms of day to day control criteria as outlined in guideline documents. Asthma outcomes are tracked somewhat crudely by available epidemiological data, such as mortality rates (7). Deaths from asthma are always regrettable and usually preventable, but they also occur relatively rarely given the widespread prevalence of the disease (8).
We, therefore, undertook the present study to determine how often Canadian patients achieved control of their asthma, how satisfied they were with their level of control and how well they understood their therapy. We also sought to understand how Canadian physicians monitor treatment outcomes in asthma, and to determine the concordance of physician and patient perspectives on the degree of control achieved.

\section{SUBJECTS AND METHODS}

The survey was conducted from September to October 1999 by The Angus Reid Group. Interviews were completed with two groups: patients with asthma and physicians. A national sample of 801 adults with asthma and 200 parents of children with asthma (aged four to 15 years) were interviewed. Asthma sufferers were defined as those who had been diagnosed with asthma by a physician and had experienced asthma symptoms in the past year; only those who had taken prescription medication for the treatment of asthma in the past year were included in the sample.

The national sample was identified by systematically screening 49,767 Canadian households using random digit dialing. The sampling was weighted by age, sex and region to conform to Statistics Canada data on asthma prevalence. The associated $95 \% \mathrm{CI}$ on the estimates of the items examined was $3.1 \%$.

A national sample of 266 physicians was also interviewed as part of the survey. The majority were general practitioners (GPs) ( $\mathrm{n}=176)$, while the remainder were specialists - 30 were allergists, 30 were pediatricians and 30 were respirologists.

\section{TABLE 1}

\section{Criteria for asthma control}

\begin{tabular}{|c|c|c|}
\hline Parameter* & Acceptable control & Poor control $^{\dagger}$ \\
\hline Daytime symptoms & Less than three days/week & Three or more days/week \\
\hline Night-time symptoms & Less than one night/week & One or more nights/week \\
\hline Physical activity & Normal & Restricted in past three months \\
\hline Exacerbations & Mild, infrequent & Any exacerbations in past month \\
\hline Absenteeism & None & $\begin{array}{c}\text { Missed school and/or work or social } \\
\text { engagement in past three months }\end{array}$ \\
\hline Short acting bronchodilator use as required & Less than three doses/week & Three or more doses/week ${ }^{\ddagger}$ \\
\hline
\end{tabular}

*Spirometry values (forced expiratory volume in $1 \mathrm{~s}$ [FEV $V_{1}$, FEV $V_{1}$ forced vital capacity, peak expiratory flow [PEF] and PEF variability) were not requested in the patient research; ${ }^{\dagger}$ Patients were classified as having poorly controlled asthma if they fell short of the acceptable levels of control outlined in the Canadian Asthma Consensus Guidelines (reference 2) on two or more of the following criteria: daytime symptoms, sleep disturbances, physical activity, asthma attacks, absenteeism and use of rescue medication; ${ }^{\ddagger}$ Not including use to prevent exercise-induced symptoms 


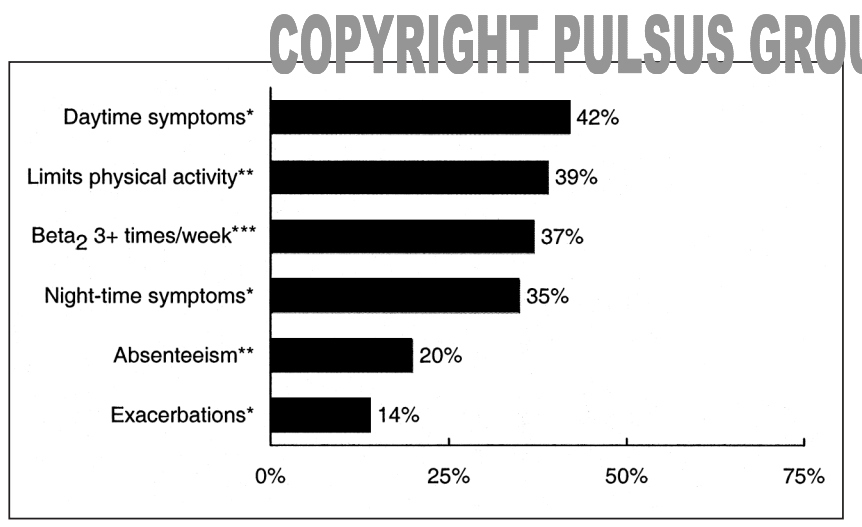

TABLE 2 00 NOT COPV

Perceived level of asthma control by patients

\begin{tabular}{lccc}
\hline $\begin{array}{l}\text { Perceived level } \\
\text { of control }\end{array}$ & $\begin{array}{c}\text { Total } \\
(\mathbf{n = 1 0 0 1 )}\end{array}$ & $\begin{array}{c}\text { Poorly controlled } \\
(\mathbf{n}=\mathbf{5 6 6})\end{array}$ & $\begin{array}{c}\text { Controlled } \\
(\mathbf{n}=\mathbf{4 3 5})\end{array}$ \\
\hline $\begin{array}{c}\text { Very well } \\
\text { controlled (\%) }\end{array}$ & 49 & 33 & 70 \\
$\begin{array}{c}\text { Adequately } \\
\text { controlled (\%) }\end{array}$ & 42 & 52 & 28 \\
$\begin{array}{c}\text { Not very well } \\
\text { controlled (\%) }\end{array}$ & 8 & 13 & 1 \\
$\begin{array}{c}\text { Not at all } \\
\text { controlled }(\%)\end{array}$ & 1 & 2 & 1 \\
\hline
\end{tabular}

Figure 1) Percentage of patients experiencing poor asthma control by parameter. *In a typical month; **During the past three months; ***During the previous week

TABLE 3

Inhaled corticosteroids: Perception and usage

\begin{tabular}{|c|c|c|c|}
\hline & $\begin{array}{l}\text { Total }(\%) \\
(n=589)\end{array}$ & $\begin{array}{l}\text { Poorly controlled (\%) } \\
\qquad(\mathrm{n}=362)\end{array}$ & $\begin{array}{l}\text { Controlled (\%) } \\
(n=227)\end{array}$ \\
\hline \multicolumn{4}{|l|}{ Perceived role of inhaled corticosteroids among current users } \\
\hline Not sure how it works or what it does & 22 & 24 & 18 \\
\hline Helps control symptoms by opening up the bronchial tubes & 26 & 26 & 26 \\
\hline Helps control asthma by reducing inflammation in airways & 52 & 50 & 56 \\
\hline \multicolumn{4}{|l|}{ Current use of inhaled corticosteroids } \\
\hline When getting an attack or having difficulty breathing & 50 & 45 & 58 \\
\hline Before exercise or doing something that may cause an attack & 24 & 28 & 17 \\
\hline Every day on a regular basis to help control asthma & 52 & 64 & 33 \\
\hline Every day during certain times of the year & 21 & 18 & 25 \\
\hline
\end{tabular}

Physicians were included if they were in active clinical practice - ie, they saw a minimum of 100 patients per week and if asthma comprised at least $5 \%$ of their patient load. The associated $95 \%$ CI on the estimates of the items examined was $6 \%$.

For the purposes of the present study, asthma control was assessed using the recommendations of the 1996 CAC Guidelines (2). Survey respondents were classified as having poorly controlled asthma if they fell short of the acceptable levels of control on at least two of the following six key parameters outlined in Table 1: daytime symptoms; sleep disturbances; physical activity; absenteeism; asthma exacerbations; and use of relief medication. The group whose asthma was considered to be controlled met the acceptable levels on at least five of the six parameters.

\section{RESULTS}

Asthma control: Only 24\% of patients achieved disease control by meeting all six symptom-based criteria listed by the 1996 CAC Guidelines as appropriate treatment targets. Fifty-seven per cent of patients failed to meet at least two of the six control criteria and were subsequently referred to as patients with poorly controlled asthma. This was due most commonly to frequent daytime symptoms, limitations in physical activities and frequent sleep disturbances (Figure 1). Twenty per cent of patients also reported missing school or work due to their asthma during the three months before the survey; $51 \%$ required an urgent visit to the physician or a visit to an emergency room in the year before the survey. By contrast, $91 \%$ of patients thought that their asthma was very well or adequately controlled. This was also the perception of $85 \%$ of those who were judged to be poorly controlled by CAC Guidelines criteria (Table 2). The great majority of respirologists and nonspecialist physicians $(90 \%$ and $77 \%$, respectively) thought that their patients achieved optimal control of their asthma.

Patients' understanding of asthma management: Among those currently using inhaled corticosteroids, one-half of patients with poorly controlled asthma were unaware of the role that inhaled corticosteroids played in reducing airway inflammation; $26 \%$ believed that inhaled corticosteroids open the bronchial tubes, while $24 \%$ were not sure of the medication's purpose (Table 3). Almost one-half (45\%) of those with poorly controlled asthma reported taking an inhaled corticosteroid when having an asthma attack, and $28 \%$ reported taking an inhaled corticosteroid before exercise (Table 3). Among current users of short acting bronchodilators (SABs), the majority (69\%) of patients with poorly controlled asthma recognized that SABs or 'rescue' medications help to control symptoms by 'opening up the bronchial tubes'. However, one in five SAB users with poorly controlled asthma believed that rescue medications reduce airway inflammation (Table 4), and one-third (34\%) used this medication daily. 
TABLE 4

COPYRIGHT PULSUS GROUP ING. " DO NOT COPY

Rescue medications for asthma: Perception and usage

\begin{tabular}{|c|c|c|c|}
\hline & $\begin{array}{l}\text { Total }(\%) \\
(n=684)\end{array}$ & $\begin{array}{l}\text { Poorly controlled (\%) } \\
\qquad(n=413)\end{array}$ & $\begin{array}{c}\text { Controlled }(\%) \\
(n=271)\end{array}$ \\
\hline \multicolumn{4}{|l|}{ Perceived role of rescue medications among current users } \\
\hline Helps control asthma by reducing inflammation in airways & 18 & 20 & 15 \\
\hline Not sure how it works or what it does & 14 & 11 & 17 \\
\hline Helps control symptoms by opening up the bronchial tubes & 68 & 69 & 68 \\
\hline \multicolumn{4}{|l|}{ Use of rescue medications } \\
\hline When getting an attack or having difficulty breathing & 90 & 91 & 88 \\
\hline Before exercise or doing something that might cause an attack & 40 & 45 & 32 \\
\hline Every day on a regular basis to help control asthma & 24 & 34 & 8 \\
\hline Every day during certain times of the year & 24 & 29 & 15 \\
\hline Do not know/not available & 4 & 3 & 7 \\
\hline
\end{tabular}

TABLE 5

Use of asthma health care resources among patients

\begin{tabular}{|c|c|c|c|c|c|}
\hline & \multirow{2}{*}{$\begin{array}{c}\text { Total }(\mathrm{n}=1001) \\
\text { Patients who used } \\
\text { the service }(\%)\end{array}$} & \multicolumn{2}{|c|}{ Poorly controlled $(n=566)$} & \multicolumn{2}{|c|}{ Controlled $(n=435)$} \\
\hline & & $\begin{array}{l}\text { Patients who used } \\
\text { the service (\%) }\end{array}$ & Visits reported (\%) & $\begin{array}{l}\text { Patients who used } \\
\text { the service (\%) }\end{array}$ & Visits reported (\%) \\
\hline $\begin{array}{l}\text { Any urgent care in past } \\
\text { year (net) }\end{array}$ & 51 & 61 & & 38 & \\
\hline Unscheduled doctor's visit & 43 & 51 & 76 & 30 & 24 \\
\hline Visit to emergency room & 28 & 34 & 78 & 19 & 22 \\
\hline Admitted to hospital & 7 & 10 & 85 & 4 & 15 \\
\hline
\end{tabular}

Adherence to CAC Guidelines: Approximately $86 \%$ of physicians said that they were aware of the CAC Guidelines; of these, $82 \%$ indicated that they used the guidelines always or most of the time. However, when asked to define how they determine whether a patient's asthma is under control, on average most physicians mentioned using only one or two criteria for assessment of control. Few physicians spoke of quantifying control of asthma in terms of frequency of symptoms as set out in the guidelines.

Patient responses to the survey offered an insight into actual physician practices. Despite the recommendation of the CAC Guidelines to use spirometry for diagnosis and assessment of control, only $54 \%$ of patients with asthma reported ever having had a lung function test. This estimate agreed well with the response by physicians to questioning about asthma control (49\% of GPs and $46 \%$ of all physicians reported using objective measures of lung function to assess control). Despite the CAC Guidelines' recommendation that patients be provided with written action plans, only $21 \%$ of patients reported receiving one. Of physicians surveyed, a similar $22 \%$ of GPs and $36 \%$ of respirologists indicated that all or most of their patients receive a written action plan. However, the purpose of the action plan as outlined in the CAC Guidelines is to help patients with asthma deal with exacerbations or flare-ups. Although most physicians (59\%) indicated that their action plans include this information, only $11 \%$ of patients recalled that their action plans included what to do during a flare-up of asthma.

Health care resource use: Patients with poorly controlled asthma accounted for most of the asthma-related emergency room visits (78\%), hospitalizations (85\%) and unscheduled doctor's visits $(76 \%)$ reported by respondents to the telephone survey (Table 5).

\section{DISCUSSION}

Our study is the first population-based review of asthma control in Canada that has addressed control in terms of the criteria for control recommended by current consensus guidelines. Our findings are discouraging: the data show that the majority of Canadians who suffer from asthma do not achieve the degree of disease control recommended by current guidelines. Approximately six in 10 Canadian patients with asthma fail to meet at least two of six symptom-based control criteria; many require urgent care for uncontrolled asthma, and miss work or school as a consequence. Most disturbingly, the majority of these patients believe that their asthma is controlled adequately. There is clearly a gap between patient expectations and what is possible with appropriate therapy. Our data also reveal specific shortcomings in physician management of asthma. Although the majority of physicians surveyed claimed familiarity with asthma control guidelines, few implemented them fully. Few physicians quantify control in terms of frequency of symptoms as set out in the guidelines, suggesting that a significant communication gap exists between patients with asthma and their health care providers. Only one-half of their patients with asthma had ever had an objective measure of lung function.

We believe that these findings will be important to the future management of asthma in Canada. Some might argue 
COPYRIGHT PULSUS GROUP that the degree of asthma control recommended in current guidelines is arbitrary and unrealistic in view of the findings. We would argue strongly that the present data show the contrary - ie, the need for more appropriate asthma management. A surprising number of patients who responded to the survey had required urgent care for the control of their disease, and many had been unable to attend work or school while their asthma was out of control. Patients with poor control in terms of day to day symptoms were most likely to use health care excessively in terms of emergency room visits, urgent visits to physicians or hospitalizations. There are substantial personal and societal costs associated with poorly controlled asthma $(9,10)$. The control of asthma in the emergency room setting is costly not only in personal terms but in direct and indirect financial costs to society as increased health care expenditures and decreased productivity.

Our survey offers specific targets for those who seek to implement the guidelines for optimal asthma management more widely. With respect to patients, our data suggest that there is a substantial need for patient education. A surprising number of patients who have asthma fail to understand the role that their various medications play. Few patients understood the role of inhaled corticosteroids or how they should be used appropriately. These findings agree with those reported by Boulet (11) who surveyed Canadian patients by telephone, and found that many were reluctant to use inhaled corticosteroids and often failed to understand the drugs' disease-modifying characteristics. In a finding that parallels that of the present study of poor patient-physician communication, few patients thought to express these concerns to their physicians (11).

We believe that in addition to providing specific information about medications and asthma management, patient education may also prove useful by raising patient expectations. That is, patients who have asthma should understand that proper management should result in few or no symptoms of the disease, and no episodes of poorly controlled asthma that result in emergency room visits or days lost from usual activities. Patients who have such expectations for their own disease management are, we believe, more likely to request appropriate care from their physicians using specific examples of suboptimal control (12). Our survey results also offer useful suggestions for implementing guidelines through continuing medical education. For example, results suggest that physicians may not question patients about their asthma control using all six symptom-based criteria as recommended in current CAC Guidelines. More comprehensive questioning of patients would likely uncover the need for greater asthma control and more appropriate intervention measures. We also note that spirometry may be suboptimally used. For example, only one-half of patients who were surveyed could recall having had an objective measure of lung function. We believe that even this figure is an overestimate; recent surveys suggest that only a minority of physicians are likely to use spirometry in their management of patients with respiratory symptoms (13). It is difficult in a telephone survey to confirm with patients the exact nature of testing that they
INC, DO NOT COPY

may have had. We suspect that some patients who were tested by peak flow measurements, or perhaps simply by chest auscultation, responded incorrectly that they had had lung function testing.

Some limitations to our study should be noted. We attempted to survey a representative sample of Canadian patients with asthma. Participation in the study was voluntary, and it is possible that our study was skewed toward patients who had poor disease control. Patients with uncontrolled disease may have had greater interest in expressing their complaints. We suspect that this bias was not present or substantial because the majority of patients we surveyed were actually content with their level of disease control. Moreover, our findings of poor disease control and excess use of bronchodilator medication is compatible with findings gathered by others. For example, Joyce and McIvor (14) reported that $52 \%$ of Canadian patients with asthma used a beta2-agonist daily, while only $41 \%$ used inhaled corticosteroids, often irregularly. As well, the Saskatchewan database study (15) showed that many Canadian patients with asthma have used large amounts of beta2-agonist and have not used appropriate disease-modifying medication with anti-inflammatory drugs. Our study was also limited in that it relied upon patients' confirmation of doctor-diagnosed asthma. It is possible that some of the patients surveyed did not suffer from asthma and may not have suffered from any respiratory disease. Recent surveys from other asthma centres have shown that a significant minority of individuals diagnosed as having asthma do not actually suffer from the disease $(16,17)$. It is also possible that some of our adult study population was contaminated or confounded by the presence of patients who actually suffered from chronic obstructive pulmonary disease. We note, however, that poor disease control documented by our survey was seen in both adult and pediatric populations. We believe that our findings are generally representative of asthma and that the majority of our study respondents did not have other respiratory disorders.

The present survey can serve as the baseline for future surveys to monitor our progress in controlling asthma in Canada. The responses to specific survey questions offer specific suggestions for appropriate implementation. It seems key that asthma education should be improved and that patients should develop greater expectations for disease control than they now have. It also seems appropriate that physicians should question patients more closely about their level of disease control and use objective monitoring more often. Implementation should take these shortcomings into account.

\section{REFERENCES}

1. Rebuck AS, Chapman KR. Asthma: 2. Trends in pharmacologic therapy. CMAJ 1987;136:483-8.

2. Ernst P, FitzGerald JM, Spier S. Canadian Asthma Consensus Conference: Summary of recommendations. Can Respir J 1996;3:89-100.

3. Sheffer AL, Bousquet J, Busse WW, et al. International consensus report on diagnosis and management of asthma. Publication \#92-3091. Bethesda: US Department of Health and Human Services, 1992.

4. The British guidelines on asthma management 1995 review and position statement - Introduction. Thorax 1997;52:S1-21.

5. Hargreave FE, Dolovich J, Newhouse MT. The assessment and 
treatment of asthma: a conference report. J'Aliergy Clin Immunol 12 . Boulet LP, Cnapman KR, Green LW, FitzGerald JM. Asthma 1990;85:1098-111.

6. Boulet LP, Becker A, Bérubé D, Beveridge R, Ernst P, for the Canadian Asthma Consensus Group. Canadian Asthma Consensus Report, 1999. CMAJ 1999;161(11 Suppl):S1-61.

7. Mao Y, Semenciw R, Morrison H, MacWilliam L, Davies J, Wigle D. Increased rates of illness and death from asthma in Canada. CMAJ 1987; 137:620-4.

8. Benatar SR. Fatal asthma. N Engl J Med 1986;314:423-9.

9. Weiss KB, Gergen PJ, Hodgson TA. An economic evaluation of asthma in the United States. Reply. N Engl J Med 1992;327:572.

10. Krahn MD, Berka C, Langlois P, Detsky AS. Direct and indirect costs of asthma in Canada, 1990. CMAJ 1996;154:821-31.

11. Boulet LP. Perception of the role and potential side effects of inhaled corticosteroids among asthmatic patients. Chest 1998;113:587-92.

education. Chest 1994;106(4 Suppl):184S-96S

13. Kesten S, Chapman KR. Physician perceptions and management of COPD. Chest 1993;104:254-8.

14. Joyce DP, McIvor RA. Use of inhaled medications and urgent care services. Study of Canadian asthma patients. Can Fam Physician 1999;45:1707-13.

15. Spitzer WO, Suissa S, Ernst P, et al. The use of $\beta$-agonists and the risk of death and near death from asthma. N Engl J Med 1992;326:501-6.

16. Dzyngel B, Kesten S, Chapman KR. Assessment of an ambulatory care asthma program. J Asthma 1994;31:291-300

17. Joyce DP, Chapman KR, Kesten S. Prior diagnosis and treatment of patients with normal results of methacholine challenge and unexplained respiratory symptoms. Chest 1996;109:697-701. 


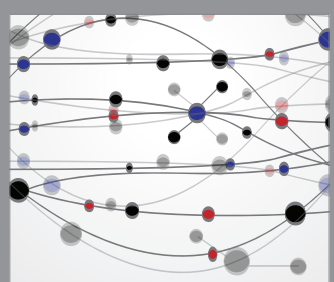

The Scientific World Journal
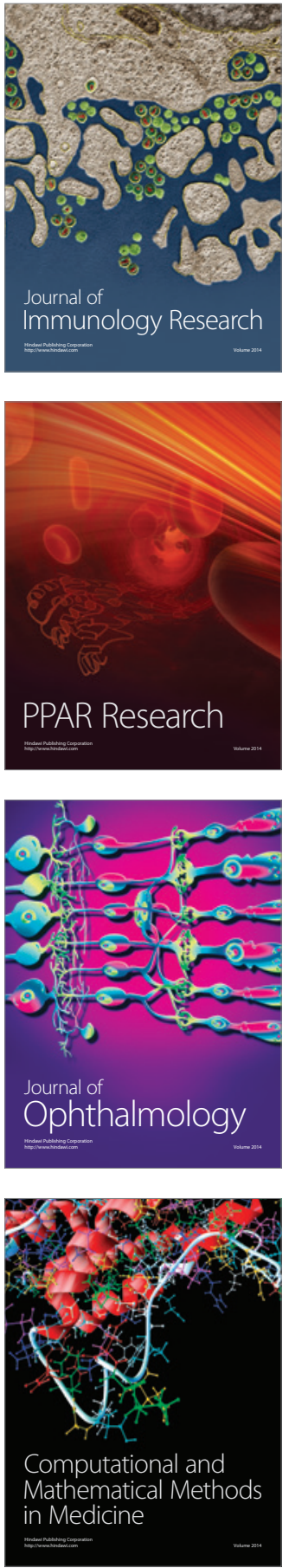

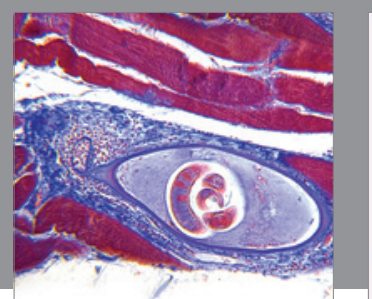

Gastroenterology Research and Practice

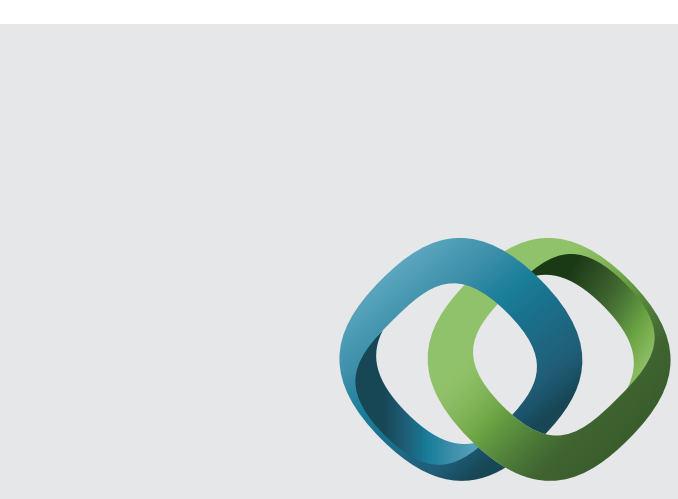

\section{Hindawi}

Submit your manuscripts at

http://www.hindawi.com
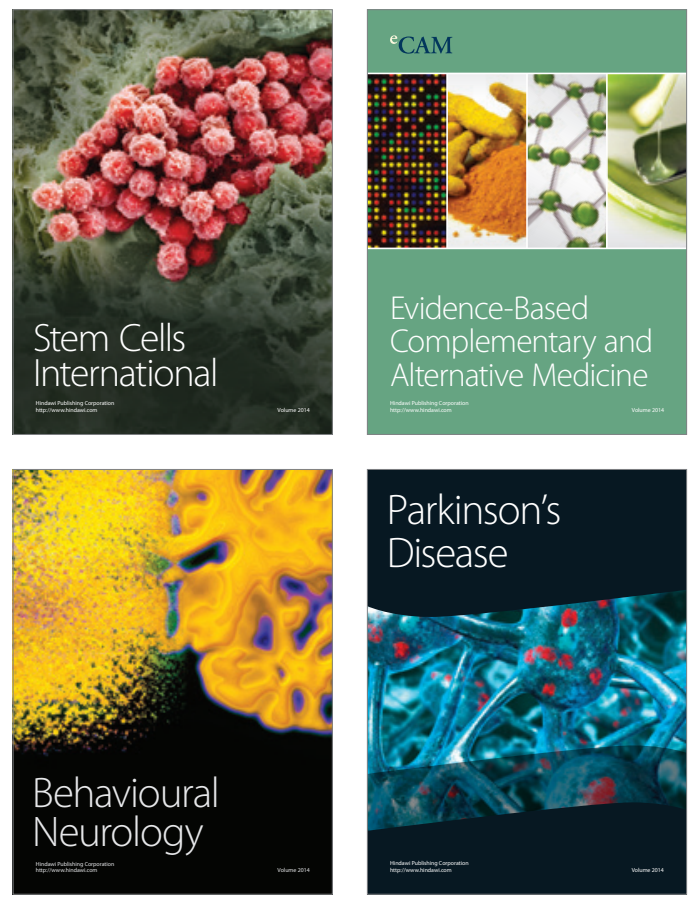
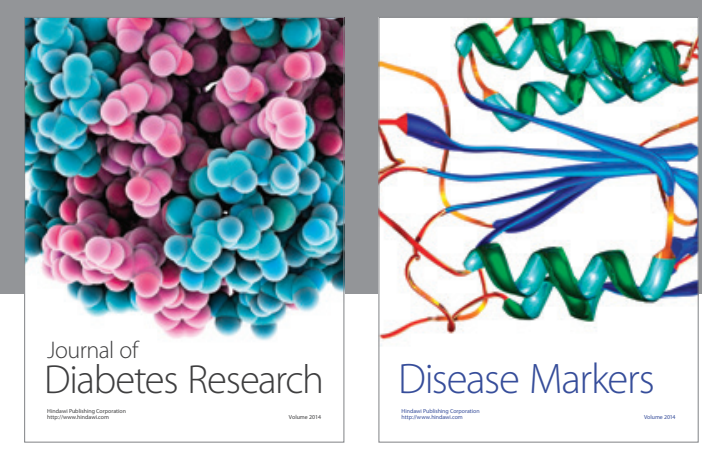

Disease Markers
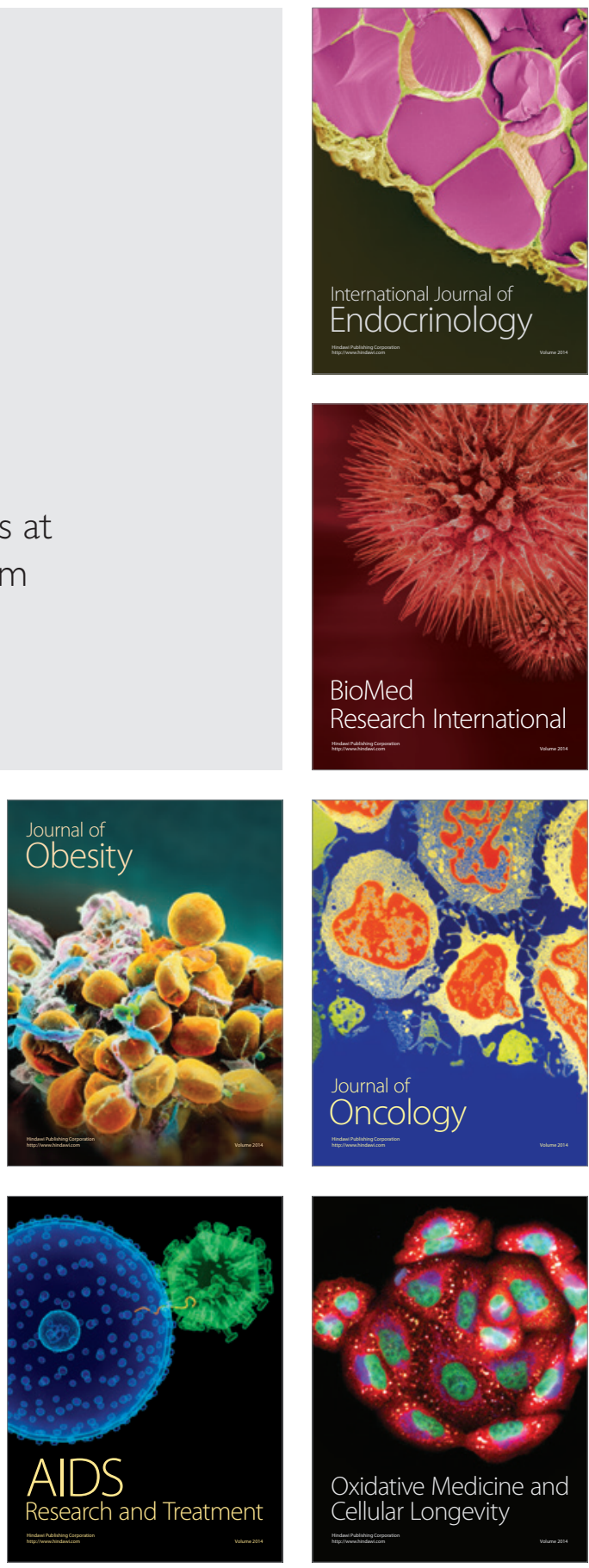